\title{
Calculation of the efficacy of vaccines against tick infestations on cattle ${ }^{\dagger}$
}

\author{
Cálculo de eficácia de vacinas contra a infestação de carrapatos nos bovinos \\ Rodrigo Casquero Cunha ${ }^{1}$; Renato Andreotti ${ }^{2 *}$; Marcos Valério Garcia ${ }^{2}$; \\ André de Abreu Rangel Aguirre'; Alexandre Leitão ${ }^{3}$
}

\begin{abstract}
${ }^{1}$ Programa de Pós-graduação em Ciência Animal, Universidade Federal de Mato Grosso do Sul - UFMS, MS, Brasil
${ }^{2}$ Departamento de Sanidade Animal, Embrapa Gado de Corte, Empresa Brasileira de Pesquisa Agropecuária - EMBRAPA, Campo Grande, MS, Brasil

${ }^{3}$ Instituto de Investigação Científica Tropical - IICT, Centro de Investigação Interdisciplinar em Sanidade Animal - CIISA, Faculdade de Medicina Veterinária, Universidade Técnica de Lisboa - UTL, Lisboa, Portugal
\end{abstract}

Received July 9, 2013

Accepted September 2, 2013

\begin{abstract}
Cattle ticks are responsible for great economic losses in cattle farming worldwide, and their main control method, chemicals, has been showing problems, whether resulting from the development of resistant strains of ticks or environmental contamination. Research studies directed toward developing vaccines against ticks are emerging. One way to evaluate those vaccines is to calculate the percentage of efficacy. The aim of this study was to analyze scientific publications archived in PubMed that used this method of assessment and discuss the main factors that may affect its calculation. Thus, 25 articles addressing this subject were selected. The percentage of efficacy was usually calculated in one of two ways, with one considering the reduced fertility of eggs and the other not. The latter method may underestimate the vaccine efficacy, and the most complete formula for calculating the efficacy reflects how much the vaccine actually affects the infestation. In our view, the use of the complete formula for calculating the percentage of efficacy is broader and more representative of the vaccine effect on the tick population.
\end{abstract}

Keywords: Efficiency, ticks, vaccine, bovine.

\section{Resumo}

Carrapatos de bovinos são responsáveis por grandes perdas econômicas para a pecuária bovina mundial e seu principal método de controle, o químico, vem apresentando problemas, seja pelo desenvolvimento de amostras de carrapatos resistentes ou pela contaminação ambiental. $\mathrm{Na}$ tentativa de diminuir a utilização dos acaricidas, surgem pesquisas direcionadas ao desenvolvimento de vacinas contra carrapatos. Uma maneira de avaliar essas vacinas é pelo cálculo de percentagem de eficácia. O objetivo deste trabalho foi analisar as publicações científicas indexadas no PubMed que utilizaram este método de avaliação e discutir os principais fatores que podem interferir no seu cálculo. Dessa maneira, selecionaram-se 25 artigos que tratavam desse assunto. A percentagem de eficácia apareceu sendo calculada de duas formas, uma considerando a redução da fertilidade dos ovos e a outra não. Essa última pode subestimar a eficiência da vacina, e a fórmula de cálculo da eficácia mais completa representa o quanto da infestação a vacina realmente reduziu. Em nosso entendimento, a utilização da fórmula completa para o cálculo da percentagem de eficácia é mais abrangente e representativa do efeito da vacina na população de carrapatos.

Palavras-chave: Eficiência, carrapato, vacina, bovino.

\footnotetext{
*Corresponding author: Renato Andreotti

Embrapa Gado de Corte, Av. Rádio Maia, 830, Zona Rural, CEP 79106-550,

Campo Grande, MS, Brasil

e-mail: andreott@cnpgc.embrapa.br

$\dagger$ This work was presented at the International Symposium on Tick Control

and Tick-borne Diseases.
} 


\section{Introduction}

Cattle ticks are ectoparasites responsible for significant economic losses, especially in tropical and subtropical regions. The control of tick infestations in cattle relies primarily on the use of acaricides. However, the selection of ticks that are resistant to existing active ingredients and the concern about environmental pollution underlie the need to develop alternative control methods. In this context, anti-tick vaccines have emerged.

The calculation of the percentage of efficacy against ticks that infect cattle is used to represent the protection of the vaccine against a given tick strain. The first investigators to test the efficacy of a vaccine against cattle ticks were Wong and Opdebeeck (1989). For this purpose, they used only three analysis parameters, which were the total number of ticks, the percentage of ticks with alterations in their normal aspect (damaged) and the total weight of the eggs. These authors also measured a fourth variable, which they termed percentage of immunoprotection. The latter variable was calculated based on the weight of the eggs from the vaccinated group compared to the weight of the eggs from the control group. Eight years later, Canales et al. (1997) calculated for the first time the proper efficacy by considering the following three variables for its calculation: total tick production, capacity of oviposition and fertility. Subsequently, Fragoso et al. (1998) used these measures when testing the commercial vaccine Gavac ${ }^{\mathrm{TM}}$ (Heber Biotec S.A., P.O. Box 6162, Havana, Cuba), which was developed as a Rhipicephalus (Boophilus) microplus control tool, in Rhipicephalus annulatus tick strains isolated from Mexico and Iran. Therefore, this calculation became a standard for other publications.

Later, Patarroyo et al. (2002) also used this measure of protection, albeit with some changes, and since then, several authors have used this measure to quantify the protection induced by their vaccines. Some authors introduced variables (DE LA FUENTE et al., 2010), and others excluded variables (AZHAHIANAMBI et al., 2009a, b; JEYABAL et al., 2010; MERINO et al., 2011) according to their laboratorial conditions and experimental design.

The purpose of this article is to analyze studies published in peer-reviewed scientific journals that calculated the percentage of vaccine efficacy against cattle ticks in the stall test by comparing the different methodological approaches.

\section{Materials and Methods}

\section{Literature review}

The Internet search to identify articles of interest was performed by the Internet Service Provider (ISP) of the Brazilian Agricultural Research Corporation - Embrapa Beef Cattle. The web search engine used was PubMed (http://www.ncbi.nlm.nih.gov/pubmed/) without search filters, using the keywords "Tick" and "Vaccine" or "Immunization" in combination. Thus, the algorithm used for the search was: TICKS AND (VACCINES OR IMMUNIZATION).

Only studies performed with vaccines against cattle ticks that were evaluated in the stall test, which calculated the percentage of efficacy and/or efficiency, were selected. Thus, studies that contemplated experimental vaccines for cattle but being tested only in other animal species were all excluded from the database, even when the calculation of percentage of efficacy was performed.

\section{Database}

A database of the main experimental variables was tabulated in Excel software. The methodology data that were unimportant for the study's experimental design were disregarded. The variables considered important were the following:

- Confounding variables: tick species, cattle breed, animal age and weight and the adjuvant used in the vaccine;

- Independent variables: type of experimental design; number of replicates; use of positive and negative controls; number and type (qualitative and quantitative) of treatments; and dose (antigen in milligrams), route and number of immunizations;

- Dependent variables: total number of engorged female ticks in the vaccinated group (NTV), total number of engorged female ticks in the negative control group (NTC), effect on the number of engorged female ticks $\{\% \mathrm{DT}=100 \mathrm{x}$ $[1-(\mathrm{NTV} / \mathrm{NTC})]\}$, mean weight of engorged female ticks in the vaccinated group (WTV), mean weight of engorged female ticks in the negative control group (WTC), effect on the weight of engorged female ticks $\{\% \mathrm{DW}=100 \mathrm{x}$ [1 - (WTV/WTC)]\}, mean weight of eggs per engorged female tick of the vaccinated group (PATV), mean weight of eggs per engorged female tick of the control group (PATC), effect on oviposition $\{\% \mathrm{DO}=100 \mathrm{x}[1-(\mathrm{PATV} /$ PATC)]\}, mean larval weight per gram of eggs in the vaccinated group (PPLOV), mean larval weight per gram of eggs in the control group (PPLOC), effect on egg fertility $\{\% \mathrm{DF}=100 \mathrm{x}[1-(\mathrm{PPLOV} / \mathrm{PPLOC})]\}$, coefficient of reduction in the number of engorged female ticks in the vaccinated/control group (CRT), coefficient of reduction in oviposition in the vaccinated/control group (CR0), coefficient of reduction in egg fertility in the vaccinated/ control group (CRF) and vaccine protection against ticks considering the effects on CRT, CTO and/or CRF $\{\%$ of Efficacy $(\% \mathrm{E})=100[1-(\mathrm{CRT} \times \mathrm{CR} 0 \mathrm{xCRF})]\}$.

Among the studies performed on infestations with heteroxenous ticks, only those reporting the percentage of the efficacy following an infestation with the parasite adult phase and estimating the $\% \mathrm{DT}, \% \mathrm{DO}$ and/or $\% \mathrm{DF}$ and $\% \mathrm{E}$ based on the collection of engorged female ticks were considered in this analysis. The calculations of the vaccine effect on the larval and nymph phases were disregarded.

The statistical tests used in the comparison analysis between the variables in the vaccinated groups in relation to their respective control groups were also assessed.

\section{Results}

A total of 1,134 articles were found with the search algorithm used. Several of those articles were focused on experimental vaccines for cattle, though they were often tested in other animal species, 
including mice (CANALES et al., 2009), rabbits (BIAN et al., 2011), sheep (ALMAZÁN et al., 2005) and deer (CARREÓN et al., 2012).

Twenty-five studies were found regarding experiments in stabled cattle (Table 1), with publication dates ranging from 1989 to 2013, which were distributed in the following 13 journals: BMC Biotechnology, Experimental Parasitology, Immunology, International Immunopharmacology, Journal of Parasitology Research, Parasite Immunology, Parasitology Research, Research in Veterinary Science, Revista Brasileira de Parasitologia Veterinária (Brazilian Journal of Veterinary Parasitology), Transboundary and Emerging Diseases, Vaccine, Veterinary Immunology and Immunopathology and Veterinary Parasitology. One of these articles was published in 1989, one in 1997, one in 1998, one in 2000, two in 2002, one in 2006, one in 2007, four in 2009, four in 2010, three in 2011 and six in 2012.

The infestation challenges were performed using Amblyomma americanum (1 paper), Hyalomma anatolicum anatolicum (5 papers), $H$. scupense (1 paper), $H$. excavatum (1 paper), $R$. annulatus (4 papers), $R$. haemaphysaloides (1 paper), $R$. (B.) microplus (17 papers) and Ixodes ricinus (1 paper).

All studies had a completely randomized design except one (CANALES et al., 1997), which failed to provide data regarding the experimental design. The number of animals per group, considering each animal to be one replicate in each assay, ranged from 3 to 16 , and the vast majority $(21 / 25)$ used 3 to 6 animals per group. Two authors failed to report the number of animals per group (CANALES et al., 1997; FRAGOSO et al., 1998), and three articles used groups with different numbers of animals (ANDREOTTI, 2006; AZHAHIANAMBI et al., 2009a; KUMAR et al., 2012a). Three studies included an unvaccinated negative control group, 21 studies vaccinated with an equal volume of saline and/or adjuvant, and one study failed to report the negative control treatment (CANALES et al., 1997). Only 6 studies used a positive control group, with 3 reporting the antigen $\mathrm{rBm} 86$ and 3 reporting the commercial vaccine Gavac ${ }^{\mathrm{TM}}$. One study used two negative control groups, with one vaccinated with the adjuvant (saponin) and another with saline only (AZHAHIANAMBI et al., 2009a).

The most common number of experimental groups was 2 (used in 11/25 studies), always including a negative control and a vaccinated group. Other studies used 3 (4/25), 4 (2/25), $5(1 / 25)$, $6(4 / 25), 8(1 / 25)$ or $18(1 / 25)$ experimental groups, all with different formulations of antigens, and one of the studies failed to clarify how many groups were used (CANALES et al., 1997). Most studies used crossbred animals (17/25). One of these studies worked with groups of crossbred and Holstein animals (CANALES et al., 1997), while another study used crossbred animals and Aberdeen Angus (FRAGOSO et al., 1998). A third study used Nellore and Simmental crossbred animals (ANDREOTTI, 2007). Three articles reported the use of European crossbred animals, albeit without specifying which breeds were involved (ALMAZÁN et al., 2010; KUMAR et al., 2012a; MERINO et al., 2011). Two other publications reported using animals of the Hereford breed (PARIZI et al., 2011; WONG; OPDEBEECK, 1989), and 3 studies used the Holstein breed (CANALES et al., 1997; GALAÏ et al., 2012; GARCÍA-GARCÍA et al., 2000). Another study did not report which breed was used (JEYABAL et al., 2010). Only three studies controlled for the weight of the animals, and one of these failed to report the mean weight of the animals (ANDREOTTI, 2006, 2007; MILLER et al., 2012). The experimental animals' ages ranged from 6 to 12 months, and six authors either did not control for or omitted this confounding variable.

All studies were qualitative in nature, with the applied dose ranging from 0.016 to $2 \mathrm{mg}$ of antigen. A dose of $0.1 \mathrm{mg}$ of antigen was used in most studies (17/25), while seven studies applied doses from $0.125 \mathrm{mg}$ to $0.4 \mathrm{mg}$, and one applied doses from $0.016 \mathrm{mg}$ to $0.5 \mathrm{mg}$ (WONG; OPDEBEECK, 1989). Only one study used a dose of $2 \mathrm{mg}$ of antigen (PATARROYO et al., 2002). Immunizations with the adjuvant Montanide were used most often (18/25), followed by saponins (5/25), aluminum hydroxide gel (2/25), Marcol 52 (1/25) and Freund's complete $(1 / 25)$. Sixteen of the studies using Montanide applied a dose of $0.1 \mathrm{mg}$ of antigen. The highest dose found was $2 \mathrm{mg}$ in a saponin adjuvant. The vast majority of studies applied 3 doses of vaccine (20/25). Four doses were applied at intervals of one month in one study (KUMAR et al., 2009), and six doses were applied at intervals of 15 days in another study. Intramuscular injection was most commonly used (16/25), followed by subcutaneous injection $(7 / 25)$. Two studies did not report the vaccine inoculation route (ANDREOTTI et al., 2012; CANALES et al., 1997).

Twenty-four studies calculated the variables NTV, NTC and DT, and only one did not calculate them (WONG; OPDEBEECK, 1989). Six studies did not calculate the variables WTV, WTC and $\%$ DW. All studies calculated the variables PATV, PATC and \%DO. Eight studies did not calculate the variables PPLOV, PPLOC and $\%$ DF. Sixteen articles used the more complete formula for calculating the efficacy by considering the variables CRT, CRO and CRF, while 7 studies only considered CRT and CRO, one considered CRO for the calculation of efficacy (WONG; OPDEBEECK, 1989) and one considered a fourth variable, designated by EF (EF = egg weight / engorged female weight), for the calculation of efficacy (ANDREOTTI et al., 2002).

Regarding the statistical tests used to compare the means of variables between the vaccinated and control groups, Student's t-test was used most frequently (13/25), followed by the analysis of variance (ANOVA; 9/25), Mann-Whitney (3/25), X²- (2/25), Tukey $(1 / 25)$ and Wilcoxon (1/19) tests. Three articles reported having used statistical software. One of them only provided the software names without reporting the command or test used (KUMAR et al., 2012b), and one study, which used the statistical analysis software (SAS) platform, reported having used the Generalized Linear Mixed Model (GLMMIX) procedure (MILLER et al., 2012).

\section{Discussion}

The calculation of a vaccine's efficacy against cattle ticks is fundamental for its evaluation. Many studies used other animal species for immunization (e.g.: ALMAZÁN et al., 2005; BIAN et al., 2011; CANALES et al., 2009) before testing in cattle for various reasons. These experiments are usually performed to test whether the vaccine is immunogenic and to optimize possible doses for subsequent use in cattle because tests in the latter species have 


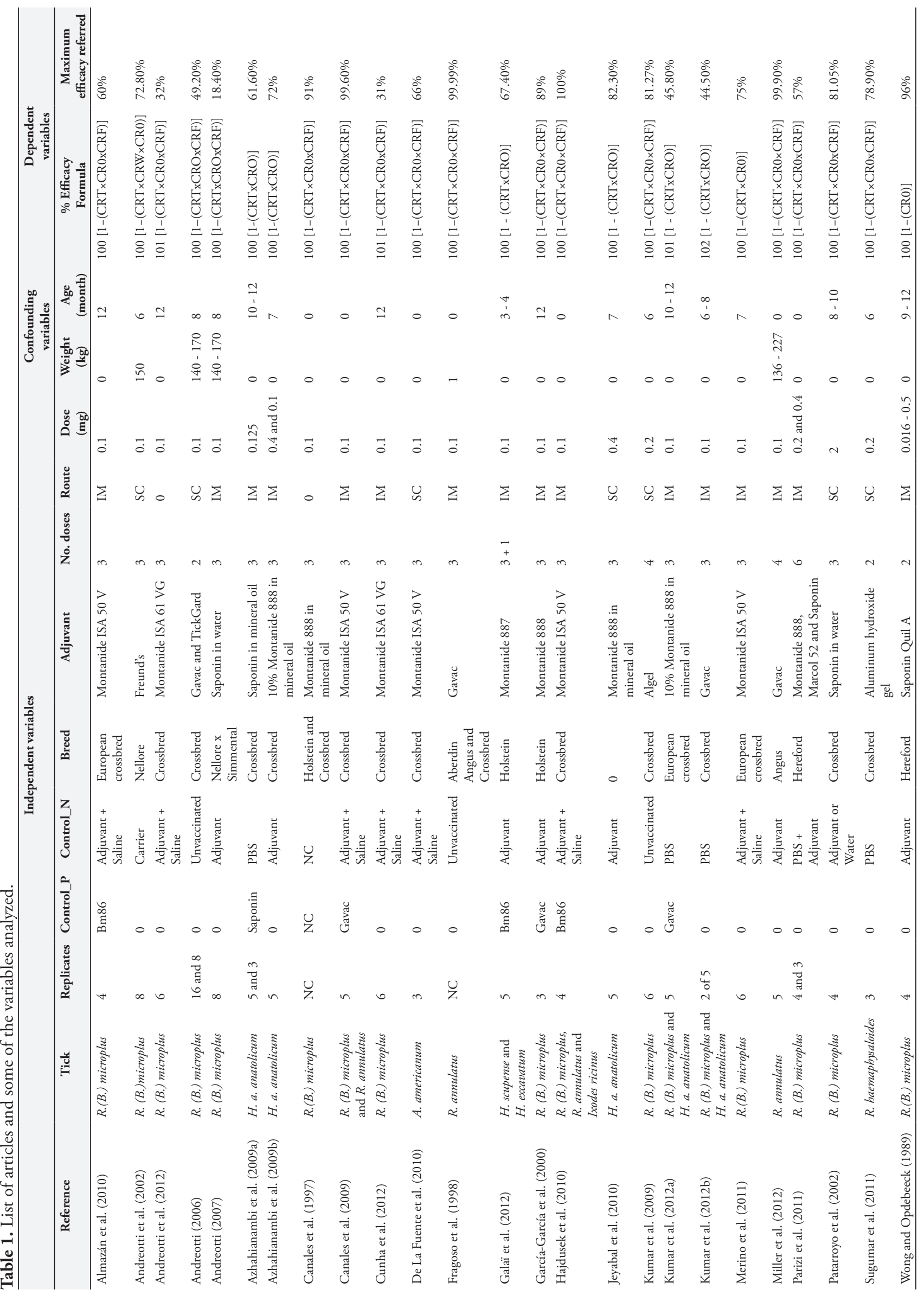


high costs and require individual and appropriate facilities for the collection of ticks. Therefore, testing in cattle is the last step in the characterization of a vaccine against ticks of this species. This may explain why only 25 studies using test methodologies in stabled cattle were found.

The journal Vaccine was the journal that published the most studies in this field (9/25), which is understandable because it is a journal directed toward the publication of new vaccine technologies. The first 3 articles on cattle tick vaccines were published in this journal (CANALES et al., 1997; FRAGOSO et al., 1998; GARCÍA-GARCÍA et al., 2000). Years later, another 6 articles were published (ANDREOTTI et al., 2012; DE LA FUENTE et al., 2010; GALAÏ et al., 2012; HAJDUSEK et al., 2010; MERINO et al., 2011; MILLER et al., 2012). Notably, all studies were published in high impact journals in the fields of veterinary medicine, parasitology and animal health.

A completely randomized design was the most commonly used study design, likely because the animals must stay in individual stalls to avoid mixing the ticks falling from an animal with those from another animal. Thus, the entire experiment may be conducted individually for each animal, considering each animal to be one replicate. The number of replicates may be considered small compared to what should be tested because the variation in tick production among animals of the same group is large. Two of the studies using 3 animals, which was the minimum used, used only 3 animals in the control group and 4 (PARIZI et al., 2011) or 5 animals (AZHAHIANAMBI et al., 2009a) in the vaccinated groups. Even studies that used 3 or 4 animals per group were able to show significant differences in the biology of tick data between the vaccinated and control groups. Some authors used 5 bovine animals per group (GALAİ et al., 2012; JEYABAL et al., 2010; KUMAR et al., 2012a, b; MILLER et al., 2012) and were able to show differences between the vaccinated and control groups in some of the biological parameters analyzed, with $\mathrm{p}<0.05$. However, other authors who used 5 replicates per group (AZHAHIANAMBI et al., 2009a, b; CANALES et al., 2009) found no significance in the comparison test between the groups. The studies that used the greatest number of replicates included two studies with 8 animals per group (ANDREOTTI, 2007; ANDREOTTI et al., 2002), which found significance at $\mathrm{p}<0.01$ for the difference in tick production between the vaccinated and control groups, and another study with 16 animals per group (ANDREOTTI, 2006), which reported having found a significant difference in the test, albeit without indicating at which level of significance or $\mathrm{p}$ value.

The use of a negative control group is crucial to assessing the mean vaccine protection because tick production in the vaccinated group is compared to the negative control group. These comparisons between dependent variables within the vaccinated groups in relation to the negative control permit the percentage of vaccine protection against ticks to be inferred. Three studies did not even simulate a vaccine application to the control group (ANDREOTTI, 2006; FRAGOSO et al., 1998; KUMAR et al., 2009), which may have affected the response variables because these animals did not endure the stress that animals in the vaccinated group may have endured, considering that they were treated under different conditions. Furthermore, an optimal negative control would include not only the application of an equal volume of a placebo (for example, saline) but also the entire vaccine composition without the antigen in question and another known antigen unrelated to ticks, for example, ovalbumin, if it was possible to apply that antigen with the same vaccine composition.

For the positive control group, it is important to note the responsiveness of the study animals to a previously studied vaccine, for example, Gavac ${ }^{\mathrm{TM}}$, thus excluding confounding variables such as the individual factor, environment and other factors related to a possible non-response of the animal to the vaccine.

All studies that used two experimental groups worked with one vaccine group and a negative control group. Although all studies were qualitative, two studies (CANALES et al., 1997; SUGUMAR et al., 2011) performed a prior quantitative test in mice to define the minimum dose to be injected in cattle. Sugumar et al. (2011), using aluminum hydroxide as an adjuvant, defined the minimum dose as $0.2 \mathrm{mg}$. It could be concluded that most vaccines were formulated with an insufficient amount of vaccine antigen if that dose could be extrapolated to the other antigens and adjuvants. However, the amount of antigen in a vaccine composition cannot be established by comparison to a different vaccine formulation. It must be established using the same vaccine formulation in the target species. Some studies using more than two treatments could have worked with different doses to determine the optimal dose, but those studies opted to use different antigens and did not mention how the best dose was chosen. Furthermore, the antibody levels needed for maximum vaccine efficacy could vary between antigens. For Bm86, there is a direct correlation between the titer of antibodies to this antigen and the efficacy of vaccination, measured through the direct effect on the fertility of the ticks engorged on vaccinated grazing cattle (DE LA FUENTE et al., 1998). There is also a correlation between antibody titers to others antigens, such as Bm95, Subolisin (SUB), Elongation Factor 1a (EF1a), Ubiquitin (UBQ), akirin (AKR) and Trypsin Inhibitor (RmLTI), and the vaccine efficacy (ALMAZÁN et al., 2012; ANDREOTTI et al., 2012; CARREÓN et al., 2012; DE LA FUENTE et al., 1998; HAVLÍKOVÁ et al., 2013; MERINO et al., 2011; MORENOCID et al., 2013). In some experiments, different Bm86 amounts were tested, and $100 \mu \mathrm{g}$ was accepted as the optimal composition (GARCÍA-GARCÍA et al., 1998; RODRÍGUEZ et al., 1994; WILLADSEN et al., 1989). Likewise, no study has tested different routes of vaccine administration or different adjuvants to establish the best way to present vaccine antigens to the immune system of cattle. Another consideration is the importance of a reproductive and safety assessment of the vaccine. For example, to demonstrate the safety of the GavacTM vaccine, its safety and effect on reproductive parameters in cattle and its toxicity in mice and guinea pigs were assessed (BOUÉ et al., 1999).

The vast majority of articles used crossbred animals in their methodology. The use of outbred animals is advantageous because the results apply to bovine animals in general, as they are more representative of the vaccine-targeted bovine population. Conversely, it is known that animals of European heritage are more susceptible to infestation by ticks, and varying degrees of breed may occur within a group of crossbred animals. Moreover, although the use of purebred cattle contributes to the homogeneity of a group, it is not 
representative of all breeds. Nevertheless, it could be an important step toward optimizing the vaccine because further testing could be conducted to test the vaccine in other more representative cattle populations, including, for example, the test field.

The confounding variable "mean weight of animals" was overlooked or omitted in most studies (21/25). Only four studies reported the weights of the animals (ANDREOTTI, 2006, 2007; ANDREOTTI et al., 2002; MILLER et al., 2012), and only one reported that the animals were weighed (FRAGOSO et al., 1998), although it failed to report whether the weight was blocked. The weight of an animal may indeed affect the results, not only because it reflects the body condition of an animal and its health status but also because smaller and leaner animals may not have the same susceptibility or resistance to ticks as heavier animals, especially considering the same breed, wherein contemporary animals usually have the same body pattern (DE LA FUENTE et al., 1998).

The best-blocked confounding variable was the age of the animals, which did not exceed 12 months. Nevertheless, 7 authors disregarded or omitted that information, which is critical for examining the possibility of prior exposure to ticks and their antigens and could affect the vaccine immune response. The use of animals that never came in contact with antigens, which are known as "naive", is common in cases of vaccine standardization. However, it is difficult to find a bovine animal that is genuinely naive because the infrastructure required for that condition would be expensive. Therefore, animals from locations free of ticks and old enough to prevent the colostrum from acting at the time of testing could be used to block that confounding variable.

The NTV, NTC and \%DT are the response variables that represent the first effect to be observed following infestation. The \%DT, which is the result of NTV/NVC, is expressed as a percentage and represents the decrease in adult ticks following vaccination under experimental infestation conditions. This variable must be considered because it not only represents the extent to which the vaccine reduced the number of adult ticks but also the decrease in larval fixation following the experimental infestation. It also represents part of the decrease in environmental infestation because the engorged female ticks fall to the ground and lay eggs, re-infesting it. Only one article disregarded this variable (WONG; OPDEBEECK, 1989), which was one of the first to study vaccines against cattle ticks in a stall test.

The WTV, WTC and \%DW are not used in the calculation of efficacy because the weight of eggs per engorged female tick (\%DO), which is used, considers the variables PATV and PATC and is proportional to the weight of engorged female ticks. However, some authors choose to consider these variables because they represent the decrease in feeding efficiency of engorged female ticks following vaccination. In this case, when considering the efficacy against ticks, it would be best to use \%DO (CRO) to calculate the efficacy because it represents the effect of the vaccination on oviposition, as not all engorged female ticks are able to lay eggs.

The PPLOV and PPLOC are calculated according to the hatchability of eggs, and the \%DF represents the percentage of decreased ability. This datum, along with the \%DT and \%DO, represents the percentage of reduction of environmental infestation.

The efficacy was calculated in two main ways: $\% \mathrm{E}=100[1-$ $\left(\mathrm{CRT} \mathrm{CRO}_{\mathrm{xCRF}}\right)$ and $\% \mathrm{E}=100[1-(\mathrm{CRT} \mathrm{xCRO})$. The latter formula fails to consider whether the eggs are fertile and may underestimate the vaccine efficacy. For example, the vaccinated group may have a normal production of eggs or even slightly above the control group, although these eggs are not as fertile as those in the control group (ANDREOTTI et al., 2012; CUNHA et al., 2012). Therefore, the most complete formula for calculating the percentage of efficacy includes the three effects and ultimately represents how much the vaccine reduced the infestation, the extent of its effect on the oviposition of ticks that survived and the fertility of the eggs that were laid were compared to the control population. The failure to use $\% \mathrm{DF}$ renders the calculation inaccurate because this datum may be negative, indicating that samples of eggs from the vaccinated group were more fertile than those in the control group. Therefore, the calculation of efficacy would be overestimated because the calculation is performed through sampling.

Regarding the statistical analysis, the test used depends on the variables to be analyzed. A concentration of values close to the mean of the group (population) usually occurs within the negative control group. In contrast, the vaccinated group exhibits a greater dispersion of those values, thereby increasing the variance given the individual factor of response to the vaccine. In those cases, we can usually use an analysis of variance (ANOVA), which analyzes whether the difference found between two groups results from the random variations in one sample compared to another or whether the data truly came from different populations. The F test may be used in combination with an ANOVA, which tests the null hypothesis that all populations have the same mean. Student's t-test may also be used for the difference between two means, and a one-way ANOVA can be considered in specific cases. Therefore, it can be established whether the vaccinated group had a specific biological parameter that was different from the control group.

The main factors that can affect the calculation of the percentage of efficacy of a vaccine against cattle ticks and, therefore, must be blocked are reported and discussed in this study. To our knowledge, using the complete formula, which includes the CRT, CRO and CRF, to calculate the percentage of efficacy is more inclusive and representative of the vaccine's effect on tick populations.

\section{References}

Almazán C, Kocan KM, Blouin EF, De La Fuente J. Vaccination with recombinant tick antigens for the control of Ixodes scapularis adult infestations. Vaccine 2005; 23(46-47): 5294-5298. http://dx.doi org/10.1016/j.vaccine.2005.08.004

Almazán C, Lagunes R, Villar M, Canales M, Rosario-Cruz R, Jongejan F, et al. Identification and characterization of Rhipicephalus (Boophilus) microplus candidate protective antigens for the control of cattle tick infestations. Parasitol Res 2010; 106(2): 471-479. http://dx.doi. org/10.1007/s00436-009-1689-1

Almazán C, Moreno-Cantú O, Moreno-Cid JA, Galindo RC, Canales $\mathrm{M}$, Villar $\mathrm{M}$, et al. Control of tick infestations in cattle vaccinated with bacterial membranes containing surface-exposed tick protective antigens. Vaccine 2012; 30(2): 265-272. http://dx.doi.org/10.1016/j. vaccine.2011.10.102 
Andreotti R. Performance of two Bm86 antigen vaccine formulation against tick using crossbreed bovines in stall test. Rev Bras Parasitol Vet 2006; 15(3): 97-100. Available from: http://www.ncbi.nlm.nih.gov/ pubmed/16978472.

Andreotti R. A synthetic bmti n-terminal fragment as antigen in bovine immunoprotection against the tick Boophilus microplus in a pen trial. Exp Parasitol 2007; 116(1): 66-70. http://dx.doi.org/10.1016/j. exppara.2006.11.009

Andreotti R, Gomes A, Malavazi-Piza KC, Sasaki SD, Sampaio CAM, Tanaka AS. BmTI antigens induce a bovine protective immune response against Boophilus microplus tick. Int Immunopharmacol 2002; 2(4): 557 563. http://dx.doi.org/10.1016/S1567-5769(01)00203-X

Andreotti R, Cunha RC, Soares MA, Guerrero FD, Leite FPL, De León AP. Protective immunity against tick infestation in cattle vaccinated with recombinant trypsin inhibitor of Rhipicephalus microplus. Vaccine 2012; 30(47): 6678-3385. http://dx.doi.org/10.1016/j. vaccine.2012.08.066

Azhahianambi P, De La Fuente J, Suryanarayana VVS, Ghosh S. Cloning, expression and immunoprotective efficacy of rHaa86, the homologue of the Bm86 tick vaccine antigen, from Hyalomma anatolicum anatolicum. Parasite Immunol 2009a; 31(3): 111-122. http://dx.doi.org/10.1111/ j.1365-3024.2008.01082.x

Azhahianambi P, Ray DD, Chaudhuri P, Gupta R, Ghosh S. Vaccine Efficacy of Bm86 Ortholog of $H$. a. anatolicum, rHaa86 Expressed in Prokaryotic Expression System. J Parasitol Res 2009b; 1-7. http://dx.doi. org/10.1155/2009/165812

Bian Y, Chen W, Yang G, Gu X, Wang S, Sun J, et al. Cloning, expression and evaluation of the efficacy of a recombinant Haemaphysalis concinna Hc-23 antigen in rabbits. Vaccine 2011; 29(5): 1041-1044. http://dx.doi. org/10.1016/j.vaccine.2010.11.062

Boué O, Redondo M, Montero C, Rodríguez M, De La Fuente J. Reproductive and safety assessment of vaccination with Gavac against the cattle tick (Boophilus microplus). Theriogenology 1999; 51(8): 1547-1554. Available from: http://dx.doi.org/10.1016/S0093-691X(99)00097-7

Canales M, Enríquez A, Ramos E, Cabrera D, Dandie H, Soto A, et al. Large-scale production in Pichia pastoris of the recombinant vaccine Gavac against cattle tick. Vaccine 1997; 15(4):414-422. http://dx.doi. org/10.1016/S0264-410X(96)00192-2

Canales M, Labruna MB, Soares JF, Prudencio CR, De La Fuente J. Protective efficacy of bacterial membranes containing surface-exposed BM95 antigenic peptides for the control of cattle tick infestations. Vaccine 2009; 27(52): 7244-7248. http://dx.doi.org/10.1016/j. vaccine.2009.09.123

Carreón D, De La Lastra JMP, Almazán C, Canales M, Ruiz-Fons F, Boadella M, et al. Vaccination with BM86, subolesin and akirin protective antigens for the control of tick infestations in white tailed deer and red deer. Vaccine 2012; 30(2): 273-279. http://dx.doi.org/10.1016/j. vaccine.2011.10.099

Cunha R, León AP, De Leite F, Pinto LDS, Santos A Jr, Andreotti R. Bovine immunoprotection against Rhipicephalus (Boophilus) microplus with recombinant Bm86-Campo Grande antigen. Rev Bras Parasitol Vet 2012; 21(3): 254-262. http://dx.doi.org/10.1590/S198429612012000300014

De La Fuente J, Manzano-Roman R, Naranjo V, Kocan KM, Zivkovic $\mathrm{Z}$, Blouin EF, et al. Identification of protective antigens by RNA interference for control of the lone star tick, Amblyomma americanum.
Vaccine 2010; 28(7): 1786-1795. http://dx.doi.org/10.1016/j. vaccine.2009.12.007

De La Fuente J, Rodríguez M, Redondo M, Montero C, García-García JC, Méndez L, et al. Field studies and cost-effectiveness analysis of vaccination with Gavac ${ }^{\mathrm{TM}}$ against the cattle tick Boophilus microplus. Vaccine 1998; 16(4): 366-373. http://dx.doi.org/10.1016/s0264410x(97)00208-9

Fragoso H, Rad PH, Ortiz M, Rodríguez M, Redondo M, Herrera $\mathrm{L}$, et al. Protection against Boophilus annulatus infestations in cattle vaccinated with the $B$. microplus Bm86-containing vaccine Gavac. Vaccine 1998; 16(20): 1990-1992. http://dx.doi.org/10.1016/S0264$410 X(98) 00116-9$

Galaï Y, Canales M, Saïd MB, Gharbi M, Mhadhbi M, Jedidi $\mathrm{M}$, et al. Efficacy of Hyalomma scupense (Hd86) antigen against Hyalomma excavatum and $H$. scupense tick infestations in cattle. Vaccine 2012; 30(49): 7084-7089. http://dx.doi.org/10.1016/j. vaccine.2012.09.051

García-García JC, Soto A, Nigro F, Mazza M, Joglar M, Hechevarría $\mathrm{M}$, et al. Adjuvant and immunostimulating properties of the recombinant Bm86 protein expressed in Pichia pastoris. Vaccine 1998; 16(9-10): 10531055. http://dx.doi.org/10.1016/S0264-410X(97)00266-1

García-García JC, Montero C, Redondo M, Vargas M, Canales M, Boué $\mathrm{O}$, et al. Control of ticks resistant to immunization with $\mathrm{Bm} 86$ in cattle vaccinated with the recombinant antigen $\mathrm{Bm} 95$ isolated from the cattle tick, Boophilus microplus. Vaccine 2000; 18(21): 2275-2287. http://dx.doi.org/10.1016/S0264-410X(99)00548-4

Hajdusek O, Almazán C, Loosova G, Villar M, Canales M, Grubhoffer $\mathrm{L}$, et al. Characterization of ferritin 2 for the control of tick infestations. Vaccine 2010; 28(17): 2993-2998. http://dx.doi.org/10.1016/j. vaccine.2010.02.008

Havlíková S, Ličková M, Ayllón N, Roller L, Kazimírová M, Slovák $\mathrm{M}$, et al. Immunization with recombinant subolesin does not reduce tick infection with tick-borne encephalitis virus nor protect mice against disease. Vaccine 2013; 31(12): 1582-1589. http://dx.doi.org/10.1016/j. vaccine.2013.01.017

Jeyabal L, Azhahianambi P, Susitha K, Ray DD, Chaudhuri P, Vanlahmuaka, et al. Efficacy of $\mathrm{rHaa} 86$, an orthologue of Bm86, against challenge infestations of Hyalomma anatolicum anatolicum. Transbound Emerg Dis v 2010; 27(1-2): 96-102. http://dx.doi.org/10.1111/j.18651682.2010.01107.x

Kumar A, Garg R, Yadav CL, Vatsya S, Kumar RR, Sugumar P, et al. Immune responses against recombinant tick antigen, Bm95, for the control of Rhipicephalus (Boophilus) microplus ticks in cattle. Vet Parasitol 2009; 165(1-2): 119-124. http://dx.doi.org/10.1016/j. vetpar.2009.06.030

Kumar B, Azhahianambi P, Ray DD, Chaudhuri P, De La Fuente J, Kumar R, et al. Comparative efficacy of $\mathrm{rHaa} 86$ and $\mathrm{rBm} 86$ against Hyalomma anatolicum anatolicum and Rhipicephalus (Boophilus) microplus. Parasite Immunol 2012a; 34(6): 297-301. http://dx.doi. org/10.1111/j.1365-3024.2012.01356.x

Kumar B, Murugan K, Ray DD, Ghosh S. Efficacy of rBm86 against Rhipicephalus (Boophilus) microplus (IVRI-I line) and Hyalomma anatolicum anatolicum (IVRI-II line) infestations on bovine calves. Parasitol Res 2012b; 111(2): 629-635. http://dx.doi.org/10.1007/ s00436-012-2879-9

Merino O, Almazán C, Canales M, Villar M, Moreno-Cid JA, Estrada-Peña A, et al. Control of Rhipicephalus (Boophilus) microplus 
infestations by the combination of subolesin vaccination and tick autocidal control after subolesin gene knockdown in ticks fed on cattle. Vaccine 2011; 29(12): 2248-2254. http://dx.doi.org/10.1016/j. vaccine. 2011.01 .050

Miller R, Estrada-Peña A, Almazán C, Allen A, Jory L, Yeater K, et al. Exploring the use of an anti-tick vaccine as a tool for the integrated eradication of the cattle fever tick, Rhipicephalus (Boophilus) annulatus. Vaccine 2012; 30(38): 5682-5687. http://dx.doi.org/10.1016/j. vaccine.2012.05.061

Moreno-Cid JA, Pérez De La Lastra JM, Villar M, Jiménez M, Pinal R, Estrada-Peña A, et al. Control of multiple arthropod vector infestations with subolesin/akirin vaccines. Vaccine 2013; 31(8): 1187-1196. http:// dx.doi.org/10.1016/j.vaccine.2012.12.073

Parizi LF, Utiumi KU, Imamura S, Onuma M, Ohashi K, Masuda A, et al. Cross immunity with Haemaphysalis longicornis glutathione S-transferase reduces an experimental Rhipicephalus (Boophilus) microplus infestation. Exp Parasitol 2011; 127(1): 113-118. http://dx.doi. org/10.1016/j.exppara.2010.07.001

Patarroyo JH, Portela RW, De Castro RO, Pimentel JC, Guzman F, Patarroyo ME, et al. Immunization of cattle with synthetic peptides derived from the Boophilus microplus gut protein (Bm86). Vet Immunol
Immunopathol 2002; 88(3-4): 163-172. Available from: http://www. ncbi.nlm.nih.gov/pubmed/12127414.

Rodríguez M, Rubiera R, Penichet M, Montesinos R, Cremata J, Falcón $\mathrm{V}$, et al. High level expression of the B. microplus Bm86 antigen in the yeast Pichia pastoris forming highly immunogenic particles for cattle. J Biotechnol 1994; 33(2): 135-146. http://dx.doi.org/10.1016/01681656(94)90106-6

Sugumar P, Chandran D, Sudha Rani G, Shahana PV, Maske DK, Rangarajan PN, et al. Recombinant mid gut antigen (Bm95) as a vaccine against Indian Rhiphicephalus haemaphysaloides in Bos indicus cattle. Res Vet Sci 2011; 90(2): 262-268. http://dx.doi.org/10.1016/j. rvsc. 2010.05 .037

Willadsen P, Riding GA, Mckenna RV, Kemp DH, Tellam RL, Nielsen JN, et al. Immunologic control of a parasitic arthropod. Identification of a protective antigen from Boophilus microplus. J Immunol 1989; 143(4): 1346-1351. Available from: http://www.ncbi. nlm.nih.gov/pubmed/2745982.

Wong JY, Opdebeeck JP. Protective efficacy of antigens solubilized from gut membranes of the cattle tick, Boophilus microplus. Immunology 1989; 66(1): 149-155. Available from: http://www. pubmedcentral.nih.gov/articlerender.fcgi?artid=1385135\&tool=pmce ntrez\&rendertype=abstract. 